\title{
The Frequencies of Six Important Thrombophilic Mutations in a Population of the Czech Republic
}

\author{
T. KVASNIČKA ${ }^{1}$, J. HÁJKOVÁ ${ }^{1}$, P. BOBČÍKOVÁ ${ }^{1}$, V. ČVERHOVÁ ${ }^{1}$, I. MALÍKOVÁ ${ }^{1}$, \\ J. ULRYCH ${ }^{2}$, J. BŘIZA ${ }^{2}$, D. DUŠKOVÁ ${ }^{3}, \breve{S}_{\text {. POLETÍNOVÁ }}^{3}$, V. KIEFEROVÁ ${ }^{3}$, \\ J. KVASNIČKA ${ }^{1}$
}

${ }^{1}$ Thrombotic Center and Central Hematological Laboratory, Institute of Medical Biochemistry and Laboratory Diagnostics, Prague, Czech Republic, ${ }^{2}$ First Surgical Department, General University Hospital and First Faculty of Medicine, Charles University in Prague, Czech Republic, ${ }^{3}$ Faculty Department of Blood Transfusion, General University Hospital and First Faculty of Medicine, Charles University in Prague, Czech Republic

Received July 19, 2013

Accepted September 18, 2013

On-line January 8, 2014

\section{Summary}

The primary aim was to determine frequencies of mutations related to risk of venous thrombosis in healthy Caucasians in Central Bohemia. In a cohort of 1527 healthy individuals the frequency of risk alleles for the mutations FV Leiden and FII $20210 \mathrm{G}>\mathrm{A}$ was $4.5 \%$ and $1.3 \%$, respectively. Frequency of 4G PAI-1 allele was $55.5 \%$. Genotype frequencies were: GG $91.03 \%$, GA $8.91 \%$, and AA $0.07 \%$ for FV Leiden; GG $97.45 \%$, GA $2.49 \%$, and AA $0.07 \%$ for FII 20210G>A; 4G/4G $30.26 \%$, 4G/5G $50.56 \%$, and 5G/5G $19.19 \%$ for PAI-1. Frequency of the risk allele $A$ in polymorphism SERPINC1 (IVS $+141 \mathrm{G}>\mathrm{A}$ ) was $11.3 \%$, and frequencies of genotypes were as follows: GG $78.36 \%$, GA $20.66 \%$, and AA $0.98 \%$. Frequency of the risk allele T for polymorphism GP6 13254T>C was $87.7 \%$, and frequencies of genotypes were as follows: TT $77.14 \%$, TC $21.15 \%$, and CC $1.70 \%$. Frequency of the risk allele $\mathrm{A}$ in polymorphism CYP4V2 (Lys259GIn) was $65.2 \%$, and frequencies of genotypes were: CC $12.25 \%$, CA $45.12 \%$, and AA $42.63 \%$. All observed genotypes and alleles frequencies were without gender differences. Their occurrences confirm a relatively high prevalence of hereditary thrombophilia predisposition in the Czech Republic.

\section{Key words}

Hereditary thrombophilia - Genotypes - Allele - Frequencies • Czech Republic

\section{Corresponding author}

T. Kvasnička, Thrombotic Center, Institute of Medical Biochemistry and Laboratory Diagnostics, General University Hospital, Charles University, Karlovo nám. 32, $121 \quad 11$ Prague 2, Czech Republic. Fax: +420 224966414. E-mail: tomas.kvasnicka@vfn.cz, tomas.kvasnicka@seznam.cz

\section{Introduction}

Venous thromboembolism (VTE) is a multifactorial disorder (Rosendaal 1999) and it is a result of interaction between different environmental factors such as trauma, hormonal therapy, pregnancy, etc., and genetic factors (Margaglione et al. 2011). The largest meta-analytic study so far (Gohil et al. 2009), may be used when determining risk of venous thromboembolism related to genetic mutations. The analysis included 173 studies conducted in approximately 126,000 cases with VTE and 184,000 controls, in whom 28 polymorphisms in 21 genes related to venous thrombophilia were tested. Only FV Leiden (FVL), FII $20210 \mathrm{G}>\mathrm{A}$, and polymorphism of a gene for inhibitor of plasminogen activator PAI-1 4G/5G (SERPINE1) complied with the criteria for moderate risk of VTE, with odds ratio greater than 1.5 (Manolio 2010).

Results of genome-wide association studies (GWAS) have been published in the last three years, involving examinations of tens- to hundreds of thousands 
of known single nucleotide polymorphisms (SNP) in cohorts containing several thousands of individuals who suffered from venous thrombosis, and healthy controls (Bezemer 2008). New examination technology called DNA microarray was used for this purpose (Manolio 2010).

The aim of our study was to determine frequency of the three already known thrombophilic mutations with clinically significant risk of VTE (FVL [Arg534Gln, rs6025] causing activated protein C resistance (Bertina et al. 1994), prothrombin F2 [20210G $>$ A, rs1799963] associated with elevated plasma prothrombin levels (Poort et al. 1996), and PAI-1 /SERPINE1/ [4G/5G, rs1799889]) inhibiting the fibrinolysis activation (Eriksson et al. 1995) as well as of three other newly detected polymorphisms related to VTE that were established in GWAS, GP6 [Ser219Pro, rs1613662] encoding the receptor glycoprotein (GP) VI that has a major role in collagen-induced platelet signaling (Riba et al. 2005), SERPINC1 [IVS +141G $>$ A, rs2227589] associated with mildly reduced antithrombin activity (de la Morena-Barrio et al. 2012), and cytochrome 450 (CYP) family gene CYP4V2 [Lys259Gln, rs13146272] which maps close to F11 gene coding for coagulation Factor XI level (Nakan et al. 2009) in a population of healthy, middle-aged individuals in the Czech Republic.

\section{Methods}

Selection of healthy population sample within the age group 18-60 years: 1,527 healthy individuals were randomly enrolled in the study; of those, 1,450 were anonymous blood donors at the Blood Bank of the General Faculty Hospital in Prague and 77 were healthy volunteers. All examinations were performed in scope of the project of the Ministry of Health, Czech Republic, No.: NT 11176-5, which has been approved by the ethics committee of the $1^{\text {st }}$ Medical Faculty of the Charles University and General Faculty Hospital in Prague. All individuals were Europeans residing in Prague or the Central Bohemia region. Other demographic data regarding this cohort are presented in Table 1.

Genome DNA was extracted from their leukocytes in peripheral blood and isolated using the MagNA Pure LC Nucleic Acid Extraction system ${ }^{\mathrm{TM}}$ with the MagNA Pure DNA Isolation Kit I $^{\mathrm{TM}}$. DNA was isolated according to the MagNA Pure High-Performance DNA Extraction ${ }^{\mathrm{TM}}$ protocol (all products supplied by Roche Diagnostics, Mannheim, Germany).
Table 1. Baseline characteristics of the study population.

\section{Characteristic}

Caucasian origin - no. of the individuals

(\%)

1527 (100)

Age, years

Mean (SD)

$35.1(9.7)$

Median

Interquartile range

$28.0-41.0$

Weight, $k g$

Mean (SD)

$79.8(14.3)$

Median

Interquartile range

$70.0-89.0$

Height, $\mathrm{cm}$

Mean (SD)

$177.0(9.0)$

Median

Interquartile range

Body mass index, $\mathrm{kg} / \mathrm{m}^{2}$

Mean (SD)

170.0 - 183.0

Median

$25.5(3.7)$

25.1

Interquartile range

Male sex - no. of the individuals (\%)

$1008(66.0)$

Female sex - no. of the individuals (\%)

Systolic blood pressure, $\mathrm{mm} \mathrm{Hg}$

Mean (SD)

519 (34.0)

Median

$119.1(10.9)$

120.0

Interquartile range

$110.0-130.0$

Diastolic blood pressure, $\mathrm{mm} \mathrm{Hg}$

Mean (SD)

$75.4(8.7)$

70.0

Median

$70.0-80.0$

Blood groups - no. of the individuals (\%)

A

$610(40.8)$

B

272 (18.2)

$A B$

$106(7.1)$

0

495 (34.0)

Smoking status - no. of the individuals (\%)

Smoker

Ex-smoker

Non-smoker

1135 (74.9)

Mutations were determined using PCR in a process called FRET (Fluorescence Resonance Energy Transfer). Tests were performed using the LightCycler ${ }^{\circledR}$ 480 System with LC $^{\circledR} 480$ Genotyping Master kits (all products supplied by Roche Diagnostics, Mannheim, Germany). Specific primers and fluorescently labelled probes were designed in cooperation with TIB MOLBIOL (Berlin, Germany), where they were custom made. Table 2 
presents sequences of used primers and probes.

The chi square test was used to determine the deviation from Hardy-Weinberg equilibrium ( $p>0.05)$ and the differencies in genotypes and alleles between males and females. The Fisher exact test was used in case of low representation of homozygous mutations. Wald's method was used to calculate a $95 \%$ confidence interval. The statistical program SAS, version 9.2 (SAS Institute, $\mathrm{NC}$, USA) with tools for population genetics was used for calculations.

Table 2. The primers and probes used for thrombophilic polymorphisms investigation.

\begin{tabular}{|c|c|c|}
\hline \multicolumn{3}{|r|}{ Factor V Leiden } \\
\hline \multirow[t]{2}{*}{ Primers } & FVR & 5‘-TgCCCAgTgCTTAACAAgACCA-3‘ \\
\hline & FVL & 5‘-CTTgAAggAAATgCCCCATTA-3‘ \\
\hline \multirow[t]{2}{*}{ Probes } & Sensor wt & 5'-ggCgAggAATACAggTAT-FL-3‘ \\
\hline & FV Anchor & 5'-LCRed640-TgTCCTTgAAgTAACCTTTCAgAAATTCTg-PH-3 \\
\hline \multicolumn{3}{|r|}{ Factor II 20210G $>$ A } \\
\hline \multirow[t]{2}{*}{ Primers } & $\mathrm{F} 2 \mathrm{~F}$ & 5‘-CCgCTggTATCAAATggg-3‘ \\
\hline & F2R & $5^{\prime}$-CCAgTAgTATTACTggCTCTTCCTg-3‘ \\
\hline \multirow[t]{2}{*}{ Probes } & F2 wt & $5^{\prime}-\mathrm{CTCAgCgAgCCTCAATg-FL-3‘}$ \\
\hline & F2 640 & 5'-LCRed640- TCCCAgTgCTATTCATgggC-PH-3“ \\
\hline \multicolumn{3}{|r|}{ SERPINE1 (PAI-1) 4G/5G } \\
\hline \multirow[t]{2}{*}{ Primers } & PAI-1 F & 5'-AgCCAgACAAggTTgTTgACAC-3“ \\
\hline & PAI-1 R & 5'-CAgAggACTCTTggTCTTTCCC-3‘ \\
\hline \multirow[t]{2}{*}{ Probes } & PAI-1 Probe & 5'-TgACTCCCCCACgTgTCC-FL-3، \\
\hline & PAI-1 Anchor & 5'-LCRed640-CCTgCTACCgAggAAggTgg-PH-3“ \\
\hline \multicolumn{3}{|r|}{ GP6 rs1613662 } \\
\hline \multirow[t]{2}{*}{ Primers } & GP6_F & 5'-CAAATCTgTgAAAgAACCAACT-3' \\
\hline & GP6_A & 5'-gATTTCCCAggAACCTCTgT-3' \\
\hline \multirow[t]{2}{*}{ Probes } & rs1613662_Anc & 5'-gCACCAgAATggACCCTgCAgAACCT-FL-3‘ \\
\hline & rs1613662_[A] & 5'-LCRed640-CCTgCTACCgAggAAggTgg-PH-3' \\
\hline \multicolumn{3}{|c|}{ SERPINC1 (antithrombin) rs2227589 } \\
\hline \multirow[t]{2}{*}{ Primers } & rs2227589 F & 5'-ggATgACATCCCCCTTgT-3، \\
\hline & rs2227589 R & 5’-CTCCAAAggACTCACAggAAT-3“ \\
\hline \multirow[t]{2}{*}{ Probes } & rs2227589 C & 5’-gCACTTgAAATgACgTCTTCC-FL-3، \\
\hline & Anc rs2227589 & 5'-LCRed640-AACAggTCTTTgACTgTAACTACCAgggA-PH-3“ \\
\hline \multicolumn{3}{|r|}{ CYP4V2 rs13146272 } \\
\hline \multirow[t]{2}{*}{ Primers } & rs13146272 S & 5’-ggCTTgATCTCTggTACCTTATgTTT-3‘ \\
\hline & rs13146272 A & 5’-CATCgTgAATgCACTTAATACCACC-3‘ \\
\hline \multirow[t]{2}{*}{ Probes } & rs13146272 C & 5'-AAAgAgCCTTCAgATCCTACATACTT-FL-3‘ \\
\hline & Anc rs13146272 & 5'-LCRed640-ACCAACAgTgTAAgTCCCTgACTTTTACAA-PH-3“ \\
\hline
\end{tabular}

\section{Results}

Determined genotypes and frequencies of the alleles FVL, FII 20210G $>$ A, PAI-1 4G/5G, GP6 (Ser219Pro, rs1613662), SERPINC1 (IVS +141G>A, rs2227589), and CYP4V2 (Lys259Gln, rs13146272) in the whole population and then separately in females and males are presented in Table 3,4 and 5. All results met the criteria of Hardy-Weinberg equilibrium. There was no gender difference $(p<0.05)$ between these frequencies. 
Table 3. The prevalence of genotypes and alleles frequencies in a population of healthy individuals in the Czech Republic.

\begin{tabular}{|c|c|c|c|c|c|c|c|c|c|c|}
\hline \multirow{3}{*}{$\begin{array}{l}\text { Chromo- } \\
\text { zome } \\
1 \mathrm{q} 23\end{array}$} & \multirow{3}{*}{$\begin{array}{l}\text { Gene } \\
\text { F5 (Leiden) }\end{array}$} & \multirow{3}{*}{$\begin{array}{l}\text { SNP } \\
\text { Arg534Gln }\end{array}$} & \multirow{3}{*}{$\begin{array}{l}\text { dbSNP ID } \\
\text { rs6025 }\end{array}$} & \multirow{2}{*}{\multicolumn{3}{|c|}{$\begin{array}{c}\text { Genotype (\%) } \\
(\mathrm{n}=1527)\end{array}$}} & \multirow{3}{*}{$\begin{array}{r}\text { Risk } \\
\text { allele }\end{array}$} & \multicolumn{2}{|c|}{$\begin{array}{c}\text { Allele frequency } \\
\text { (95\% confidence interval) }\end{array}$} & \multirow{3}{*}{$\begin{array}{c}\text { HWE } \\
\mathrm{P}=0.3564\end{array}$} \\
\hline & & & & & & & & \multirow{2}{*}{$\begin{array}{c}\mathbf{p} \\
\mathrm{G}=0.955 \\
(0.947-0.962)\end{array}$} & \multirow{2}{*}{$\begin{array}{c}\mathbf{q} \\
\mathrm{A}=0.045 \\
(0.038-0.053)\end{array}$} & \\
\hline & & & & $\begin{array}{c}\text { GG } \\
91.03\end{array}$ & $\begin{array}{r}\text { GA } \\
8.91\end{array}$ & $\begin{array}{l}\mathrm{AA} \\
0.07\end{array}$ & & & & \\
\hline $11 p 11-12 q$ & $\mathrm{~F} 2$ & $20210 \mathrm{G}>\mathrm{A}$ & rs1799963 & $\begin{array}{c}\mathrm{GG} \\
97.45\end{array}$ & $\begin{array}{c}\mathrm{GA} \\
2.49\end{array}$ & $\begin{array}{l}\text { AA } \\
0.07\end{array}$ & A & $\begin{array}{c}G=0.987 \\
(0.982-0.991)\end{array}$ & $\begin{array}{c}\mathrm{A}=0.013 \\
(0.009-0.018)\end{array}$ & $\mathrm{P}=0.2325$ \\
\hline $7 \mathrm{q} 21.3-\mathrm{q} 22$ & SERPINE1 & $4 \mathrm{G} / 5 \mathrm{G}$ & rs 1799889 & $\begin{array}{l}5 \mathrm{G} 5 \mathrm{G} \\
18.97\end{array}$ & $\begin{array}{l}5 \mathrm{G} 4 \mathrm{G} \\
50.34\end{array}$ & $\begin{array}{l}4 \mathrm{G} 4 \mathrm{G} \\
30.69\end{array}$ & $4 \mathrm{G}$ & $\begin{array}{c}4 \mathrm{G}=0.555 \\
(0.540-0.574)\end{array}$ & $\begin{array}{c}5 \mathrm{G}=0.445 \\
(0.426-0.460)\end{array}$ & $\mathrm{P}=0.3550$ \\
\hline $19 \mathrm{q} 13.4$ & GP6 & Ser219Pro & rs 1613662 & $\begin{array}{c}\text { TT } \\
77.14\end{array}$ & $\begin{array}{c}\mathrm{TC} \\
21.15\end{array}$ & $\begin{array}{l}\mathrm{CC} \\
1.70\end{array}$ & $\mathrm{~T}$ & $\begin{array}{c}\mathrm{T}=0.877 \\
(0.866-0.889)\end{array}$ & $\begin{array}{c}\mathrm{C}=0.123 \\
(0.111-0.134)\end{array}$ & $\mathrm{P}=0.4794$ \\
\hline $1 q 23-q 25.1$ & SERPINC1 & $\mathrm{IVS}+141 \mathrm{G}>\mathrm{A}$ & rs 2227589 & $\begin{array}{c}\mathrm{GG} \\
78.36\end{array}$ & $\begin{array}{c}\text { GA } \\
20.66\end{array}$ & $\begin{array}{l}\text { AA } \\
0.98\end{array}$ & A & $\begin{array}{c}\mathrm{G}=0.887 \\
(0.875-0.898)\end{array}$ & $\begin{array}{c}A=0.113 \\
(0.102-0.125)\end{array}$ & $\mathrm{P}=0.2494$ \\
\hline $4 q 35.2$ & CYP4V2 & Lys259Gln & rs 13146272 & $\begin{array}{c}\mathrm{AA} \\
42.63\end{array}$ & $\begin{array}{c}\mathrm{AC} \\
45.12\end{array}$ & $\begin{array}{c}\mathrm{CC} \\
12.25\end{array}$ & A & $\begin{array}{c}A=0.652 \\
(0.635-0.669)\end{array}$ & $\begin{array}{c}C=0.348 \\
(0.331-0.365)\end{array}$ & $\mathrm{P}=0.8214$ \\
\hline
\end{tabular}

Table 4. The prevalence of genotypes and alleles frequencies in a population of healthy males in the Czech Republic.

\begin{tabular}{|c|c|c|c|c|c|c|c|c|}
\hline \multicolumn{9}{|c|}{ Males } \\
\hline \multirow[t]{2}{*}{ Gene } & \multirow[t]{2}{*}{ SNP } & \multirow[t]{2}{*}{ dbSNP ID } & \multirow{2}{*}{\multicolumn{3}{|c|}{$\begin{array}{c}\text { Genotype (\%) } \\
(\mathrm{n}=1008)\end{array}$}} & \multicolumn{2}{|c|}{$\begin{array}{c}\text { Allele frequency } \\
\text { (95\% confidence interval) }\end{array}$} & \multirow[t]{2}{*}{ HWE } \\
\hline & & & & & & $\mathbf{p}$ & $\mathbf{q}$ & \\
\hline F5 (Leiden) & Arg534Gln & rs 6025 & $\begin{array}{c}\mathrm{GG} \\
91.07\end{array}$ & $\begin{array}{c}\text { GA } \\
8.83\end{array}$ & $\begin{array}{l}\text { AA } \\
0.10\end{array}$ & $\begin{array}{c}\mathrm{G}=0.955 \\
(0.945-0.964)\end{array}$ & $\begin{array}{c}A=0.045 \\
(0.036-0.055)\end{array}$ & $\mathrm{P}=0.7183$ \\
\hline F2 & $20210 \mathrm{G}>\mathrm{A}$ & rs 1799963 & $\begin{array}{c}\mathrm{GG} \\
97.52\end{array}$ & $\begin{array}{c}\text { GA } \\
2.48\end{array}$ & $\begin{array}{l}\mathrm{AA} \\
0.00\end{array}$ & $\begin{array}{c}G=0.988 \\
(0.983-0.992)\end{array}$ & $\begin{array}{c}A=0.012 \\
(0.008-0.017)\end{array}$ & $\mathrm{P}=1.0000$ \\
\hline SERPINE1 & $4 \mathrm{G} / 5 \mathrm{G}$ & rs1799889 & $\begin{array}{l}5 \mathrm{G} 5 \mathrm{G} \\
19.15\end{array}$ & $\begin{array}{l}5 \mathrm{G} 4 \mathrm{G} \\
50.69\end{array}$ & $\begin{array}{l}4 \mathrm{G} 4 \mathrm{G} \\
30.16\end{array}$ & $\begin{array}{c}4 \mathrm{G}=0.555 \\
(0.534-0.576)\end{array}$ & $\begin{array}{c}5 \mathrm{G}=0.445 \\
(0.424-0.466)\end{array}$ & $\mathrm{P}=0.4031$ \\
\hline GP6 & Ser219Pro & rs 1613662 & $\begin{array}{c}\mathrm{TT} \\
76.19\end{array}$ & $\begin{array}{c}\mathrm{TC} \\
21.53\end{array}$ & $\begin{array}{c}\mathrm{CC} \\
2.28\end{array}$ & $\begin{array}{c}\mathrm{T}=0.870 \\
(0.855-0.884)\end{array}$ & $\begin{array}{c}\mathrm{C}=0.131 \\
(0.116-0.145)\end{array}$ & $\mathrm{P}=0.1046$ \\
\hline SERPINC1 & IVS $+141 \mathrm{G}>\mathrm{A}$ & rs 2227589 & $\begin{array}{c}\mathrm{GG} \\
77.73\end{array}$ & $\begin{array}{c}\mathrm{GA} \\
21.17\end{array}$ & $\begin{array}{l}\text { AA } \\
1.09\end{array}$ & $\begin{array}{c}\mathrm{G}=0.883 \\
(0.870-0.897)\end{array}$ & $\begin{array}{c}A=0.117 \\
(0.103-0.130)\end{array}$ & $\mathrm{P}=0.4051$ \\
\hline CYP4V2 & Lys259Gln & rs 13146272 & $\begin{array}{c}\mathrm{AA} \\
41.47\end{array}$ & $\begin{array}{c}\mathrm{AC} \\
45.44\end{array}$ & $\begin{array}{c}\mathrm{CC} \\
13.10\end{array}$ & $\begin{array}{c}A=0.642 \\
(0.621-0.663)\end{array}$ & $\begin{array}{c}C=0.358 \\
(0.337-0.380)\end{array}$ & $P=0.7101$ \\
\hline
\end{tabular}

Table 5. The prevalence of genotypes and alleles frequencies in a population of healthy females in the Czech Republic.

\begin{tabular}{|c|c|c|c|c|c|c|c|c|}
\hline \multicolumn{9}{|c|}{ Females } \\
\hline \multirow[t]{2}{*}{ Gene } & \multirow[t]{2}{*}{ SNP } & \multirow[t]{2}{*}{ dbSNP ID } & \multirow{2}{*}{\multicolumn{3}{|c|}{$\begin{array}{c}\text { Genotype (\%) } \\
\quad(\mathrm{n}=519)\end{array}$}} & \multicolumn{2}{|c|}{$\begin{array}{c}\text { Allele frequency } \\
(95 \% \text { confidence interval) }\end{array}$} & \multirow[t]{2}{*}{ HWE } \\
\hline & & & & & & $\mathbf{p}$ & $\mathbf{q}$ & \\
\hline F5 (Leiden) & Arg534Gln & rs 6025 & $\begin{array}{c}\mathrm{GG} \\
90.94\end{array}$ & $\begin{array}{l}\text { GA } \\
9.06\end{array}$ & $\begin{array}{l}\text { AA } \\
0.00\end{array}$ & $\begin{array}{c}\mathrm{G}=0.955 \\
(0.942-0.966)\end{array}$ & $\begin{array}{c}\mathrm{A}=0.045 \\
(0.034-0.058)\end{array}$ & $\mathrm{P}=0.6247$ \\
\hline $\mathrm{F} 2$ & $20210 \mathrm{G}>\mathrm{A}$ & rs1799963 & $\begin{array}{c}\mathrm{GG} \\
97.30\end{array}$ & $\begin{array}{l}\mathrm{GA} \\
2.50\end{array}$ & $\begin{array}{l}\text { AA } \\
0.19\end{array}$ & $\begin{array}{c}\mathrm{G}=0.986 \\
(0.978-0.993)\end{array}$ & $\begin{array}{c}A=0.015 \\
(0.007-0.022)\end{array}$ & $\mathrm{P}=0.0950$ \\
\hline SERPINE1 & $4 \mathrm{G} / 5 \mathrm{G}$ & rs1799889 & $\begin{array}{l}5 \mathrm{G} 5 \mathrm{G} \\
19.27\end{array}$ & $\begin{array}{l}5 \mathrm{G} 4 \mathrm{G} \\
50.29\end{array}$ & $\begin{array}{l}4 \mathrm{G} 4 \mathrm{G} \\
30.44\end{array}$ & $\begin{array}{c}4 \mathrm{G}=0.556 \\
(0.529-0.589)\end{array}$ & $\begin{array}{c}5 \mathrm{G}=0.444 \\
(0.411-0.471)\end{array}$ & $P=0.6734$ \\
\hline GP6 & Ser219Pro & rs1613662 & $\begin{array}{c}\text { TT } \\
79.00\end{array}$ & $\begin{array}{c}\mathrm{TC} \\
20.42\end{array}$ & $\begin{array}{c}\mathrm{CC} \\
0.58\end{array}$ & $\begin{array}{c}\mathrm{T}=0.892 \\
(0.874-0.911)\end{array}$ & $\begin{array}{c}\mathrm{C}=0.108 \\
(0.089-0.126)\end{array}$ & $\mathrm{P}=0.1653$ \\
\hline SERPINC1 & IVS $+141 \mathrm{G}>\mathrm{A}$ & rs2227589 & $\begin{array}{c}\mathrm{GG} \\
79.58\end{array}$ & $\begin{array}{c}\text { GA } \\
19.65\end{array}$ & $\begin{array}{l}\mathrm{AA} \\
0.77\end{array}$ & $\begin{array}{c}\mathrm{G}=0.894 \\
(0.877-0.912)\end{array}$ & $\begin{array}{c}\mathrm{A}=0.106 \\
(0.088-0.123)\end{array}$ & $\mathrm{P}=0.3969$ \\
\hline CYP4V2 & Lys259Gln & rs 13146272 & $\begin{array}{c}\text { AA } \\
44.89\end{array}$ & $\begin{array}{c}\mathrm{AC} \\
44.51\end{array}$ & $\begin{array}{c}\mathrm{CC} \\
10.60\end{array}$ & $\begin{array}{c}A=0.672 \\
(0.642-0.701)\end{array}$ & $\begin{array}{c}C=0.329 \\
(0.299-0.358)\end{array}$ & $\mathrm{P}=0.8404$ \\
\hline
\end{tabular}




\section{Discussion}

It is well known that prevalence of FVL and FII $20210 \mathrm{G}>\mathrm{A}$ mutations in a population is mainly established by ethnic origin. A large epidemiologic study conducted in the USA presented a $5.27 \%$ incidence of heterozygous FVL mutation in European individuals, $2.21 \%$ in Latinos, $1.23 \%$ in Afro-Americans, $1.25 \%$ in American Indians, and only $0.45 \%$ in Asians. Similarly, low or zero incidence of the FII $20210 \mathrm{G}>$ A mutation was found in non-European population (Ridker et al. 1997). European incidence of FVL heterozygotes varies between 2-15\% (Lucotte et al. 2001), and between 1-5\% in the case of FII 20210G $>$ A (Bertina 1998). Relatively high differences in various European regions are probably due to past migration of population. FVL heterozygotes have prevalence of $4 \%$ in the Slovak Republic and thus similar composition to the Czech Republic's population can be assumed (Honzak 1999). Germany has $7.8 \%$ prevalence of FVL, and $3.5 \%$ of FII 20210G $>$ A heterozygotes (Hoppe et al. 2006). In the north-south axis, an uneven geographic incidence of FVL should be expected (Schwender 1997). If a more appropriate epidemiologic parameter - the frequency of mutated alleles - is used, the ranges are 1.6-4\% for F5 1691A allele, and $1 \%$ for $F 220210 \mathrm{~A}$ allele in the neighbouring states (Renner et al. 2000, Adler et al. 2010). The first data regarding FVL mutation prevalence in healthy population of the Czech Republic were presented in 1998 with a prevalence of heterozygotes of $6.5 \%(8.2 \%$ of females and $4.92 \%$ of males) and a total frequency of mutated allele $4.1 \%$ (Matyskova et al. 1999). In 1999, the first data on FII $20210 \mathrm{G}>\mathrm{A}$ mutation in the Czech population were presented by Hrachovinova et al. (1999) with a prevalence of heterozygotes of $3.4 \%$. Incidence of the homozygous PAI-1 4G/4G mutation is rather high in the European population. For example, in Germany the distribution of $4 \mathrm{G} / 4 \mathrm{G}$ homozygotes is $29.4 \%, 4 \mathrm{G} / 5 \mathrm{G}$ heterozygotes $48.2 \%$, and wild type genotype $5 \mathrm{G} / 5 \mathrm{G}$ $22.3 \%$, with frequency of the variant allele $4 \mathrm{G}$ up to $57.6 \%$ (Hoppe et al. 2006). Data on prevalence of PAI-1 polymorphism in the Czech Republic were published in two studies so far. Buckova et al. (2002) presented the following genotype frequencies in healthy individuals: PAI-1 4G/4G 28.5 \%, PAI-1 4G/5G 44.6\%, and PAI-1 5G/5G 26.9\%. Hubacek et al. (2010) observed the incidence of $4 \mathrm{G} / 4 \mathrm{G}, 4 \mathrm{G} / 5 \mathrm{G}$ and $5 \mathrm{G} / 5 \mathrm{G}$ genotypes in $29.7 \%, 49.7 \%$, and $20.6 \%$ of healthy males and in $31.8 \%, 46.6 \%$ and $21.6 \%$ of females, respectively. Our data suggest that prevalence of FVL as well as FII 20210G $>$ A and PAI-1 in healthy individuals in Prague and Central Bohemian regions does not differ significantly from that in neighbouring Germany and Austria. FVL prevalence, however, seems to be somewhat lower in the Slovak Republic and in Poland. Lower FVL prevalence in healthy population $(3.5 \%$ heterozygotes) was detected even farther east, in Ukraine (Tatarskyy et al. 2010). The PAI-1, however, is an acute phase protein, and, apart from the influence of this mutation, its synthesis is affected by other factors that include the activity of a variety of hormones, cytokines (IL-1 beta, TNF-alpha, or IL-6), and the time of day (Kruithof 2008).

According to GWAS, the additional three polymorphisms associated with venous thrombosis have a rather low odds ratio. Antithrombin gene polymorphism (SERPINC1, IVS $+141 \mathrm{G}>\mathrm{A}$, rs2227589) is related to a very small increase in risk of venous thromboembolism (estimated odds ratios for minor allele A were 1.42, 1.24, and 1.29, respectively, in case-control studies LETS, MEGA-1, and MEGA-2) (Bezemer et al. 2008). But other case-control studies, however, did not confirm this correlation (Austin et al. 2011). The presence of risk allele $\mathrm{A}$ is related to mild prothrombogenic functional defect in its carriers - lower inhibition of F Xa (genotype AA $94.6 \pm 8.4 \%$ ) and concentration of antithrombin (AA $94.8 \pm 5.6 \%$ ) than in individuals with genotype GG $(97.0 \pm 7.3 \%$ and $99.5 \pm 5.8$ respectively). Frequency of SERPINC1 IVS $+141 \mathrm{G}>\mathrm{A}$ genotype was $80.5 \% \mathrm{GG}$, $18.1 \% \mathrm{GA}$, and $1.3 \% \mathrm{AA}$, with frequency of allele $\mathrm{A}$ $12 \%$ in healthy individuals of European origin in Spain (Antón et al. 2009). The MEGA-2 study in Netherlands presented the following rates: $82 \% \mathrm{GG}, 17 \% \mathrm{GA}$, and $1 \%$ AA, with frequency of allele A $11 \%$ (Bezemer et al. 2008). Frequency of the minor allele in healthy American Caucasians was determined to be $11 \%$, with frequency of genotype CC $79.82 \%$, CT $19.13 \%$, and TT $1.05 \%$ (Watkins et al. 2006). Our study detected similar frequency $(11.3 \%)$ of the minor risk allele $\mathrm{A}$. The platelet receptor for collagen glycoprotein VI (GPO) is found in human thrombocytes and megakaryocytes, but not in other human cells (Clemetson et al. 1999). Functional differences were described between the incidence of major (a) and minor (b) haplotype that encodes isoforms of GP6 with amino acids SKTQH or PEALN at sites 219, 237, 249, 317, and 322 (mutations GP6 655T $>$ C, 709A $>$ G, 745A $>$ G, 950A $>$ T, and 964C $>A$, respectively) (Takagi et al. 2002). Incidence of minor 
allele GP6 (haplotype b) or its representative GP6 mutation 655T $>C$ (Ser219Pro, 13254T $>C$, rs1613662) was investigated mainly in relation to atherothrombosis or myocardial infarction, however, with contradictory findings (Croft et al. 2001, Bray et al. 2007, Motovska et al. 2010). However, another large study, SMILE (Snoep et al. 2010), did not confirm the correlation of GP6 mutation with heart attack, recurrence of cardiovascular events, or a higher mortality. According to in vitro tests, a minor variant of GP6 results in reduction of platelet reactivity with the agonist (collagen); this was attributed to lower expression of this receptor on platelet surface (Joutsi-Korhonen et al. 2003) and to functional defect on the level of constitutionally activated Src-tyrosine kinase Fyn/Lyn in immunoreceptor tyrosine-based activation motif (ITAM) (Trifiro et al. 2009). GWAS also described a somewhat protective effect of the GP6 13254T $>\mathrm{C}$ mutation (specifically, its haplotype b) in regard of venous thromboembolism incidence, with odds ratio 0.80-0.87 (Tregouet et al. 2009). Risk of venous thromboembolism should be related to incidence of the major haplotype a and allele $\mathrm{T}$ (odds ratio 1.36-1.5). However, this assumption was not confirmed by a repeated case-control study conducted by Austin et al. (2011) in Americans of European origin, where the odds ratio for this major allele was only 1.04. Watkins et al. (2006) determined the incidence of $\mathrm{T}$ allele as $85 \%$, and $\mathrm{C}$ allele as $15 \%$ in Europeans. Caucasian Americans had similar frequency of the major allele (84\%), with genotype frequency TT $71.04 \%$, TC $29.40 \%$, and CC $2.56 \%$. Our study in healthy Czech corresponds with frequencies in European population, with slight dominance of the major allele and lower frequency of the minor allele.

Third polymorphism - CYP4V2 rs13146272 (Lys259Gln, substitution of alleles $\mathrm{A}>\mathrm{C}$ ) - is also associated with the risk of venous thromboembolism. So far, however, there is no known association of this gene with blood coagulation or function of platelets. Previously known mutations of CYP4V2 result in metabolic disorder of fatty acids called the Bietti progressive crystal dystrophy of the cornea and retina (Li et al. 2004). Three association studies (Bezemer et al. 2008, Tregouet et al. 2009, Austin et al. 2011) confirmed that minor allele $\mathrm{C}$ of the new gene polymorphism CYP4V2 registered in the SNP database as rs13146272 (Lys259Gln) is found in smaller number of individuals with venous thrombosis than in the control population. The major allele $\mathrm{A}$ is considered a risk of venous thrombosis, with odds ratio 1.24 . It can be related to the activity of coagulation factor XI with its gene located close to gene CYP4V2 (Morange et al. 2011). Li et al. (2009) in a wide haplotype study confirmed that two polymorphisms of the gene $F \quad 11$ rs2289252 and rs2036914 related to higher level of FXI are also present in haplotypes that contain risk allele A of polymorphism CYP4V2 rs13146272. Thus, the mutation CYP4V2 (Lys259Gln) is only a marker for higher risk in development of VTE. Control population samples containing European individuals without venous thromboembolism detected following frequencies of the major allele A (rs13146272 CYP4V2): in Dutch individuals $64-65 \%$, with frequency of the minor allele 35-36\%, and genotype frequency (MEGA-2 study) CC $13 \%$, CA $45 \%$, and AA $42 \%$; in French individuals 63-67\% frequency of the risk allele $\mathrm{A}$, and 33-37\% frequency of the minor allele $\mathrm{C}$ (odds ratio 0.84); in Caucasian Americans $62 \%$ frequency of the allele $\mathrm{A}$ and $38 \%$ frequency of the allele $\mathrm{C}$, with genotype incidence CC $15.43 \%$, CA $45.84 \%$, and AA $38.73 \%$ (Bezemer et al. 2008, Tregouet et al. 2009, Austin et al. 2011). In our population, the following results were obtained: frequency of the major risk allele $\mathrm{A}$ was $65.2 \%$; frequency of the minor allele $\mathrm{C}$ was $34.8 \%$; genotype frequency of $\mathrm{CC}$ was $12.25 \%$, of CA $45.12 \%$, and of AA $42.63 \%$. These results are very similar to those in other monitored European populations.

\section{Conclusions}

The data presented in our study showed in healthy Czech population a prevalence of well known thrombophilia mutations, conferring a moderate risk of thrombosis, Factor V Leiden and Factor II 20210G $>$ A of $4.5 \%$ and $1.3 \%$, respectively. These figures are comparable with data from other countries in the Central European region. In accordance with published results we found a high prevalence of polymorphisms of PAI-1 as well as of the three novel susceptibility genes for VTE (GP6, SERPINEC1 and CYP4V2), suggesting these polymorphisms to confer only a modest increase in the risk of VTE. The risk is probably increased in individuals with concurrent presence of several these polymorphisms. The clinical importance of their laboratory detection, however, should be documented by future studies in subjects with VTE. 


\section{Conflict of Interest}

There is no conflict of interest.

\section{Acknowledgements}

This study was supported by the research projects NT 11176-5 and RVO-VFN 64165 of Ministry of Health, Czech Republic.

\section{Abbreviations}

SNP - single nucleotide polymorphism; dbSNP ID database of SNPs identification; rs - reference SNP ID; p - "major"allele frequency; q - "minor"allele frequency; HWE - Hardy-Weinberg equilibrium; F5 - coagulation factor V, FV; FVL - Factor V Leiden; F2 - coagulation factor II, FII, prothrombin; PAI-1 - plasminogen activator inhibitor type 1; F11 - coagulation factor XI, FXI; SERPINE1 - serpin peptidase inhibitor, clade E (plasminogen activator inhibitor type 1, PAI-1), member 1; SERPINC1 - serpin peptidase inhibitor, clade C (antithrombin), member 1; GP6 - glycoprotein VI; CYP4V2 - cytochrome P450, family 4, subfamily V, polypeptide 2; PCR - Polymerase Chain Reaction; VTE venous thromboembolism; OR - odds ratio; GWAS genome wide association study; LD - linkage disequilibrium; SMILE - Study of Myocardial Infarctions in Leiden.

\section{References}

ADLER G, PARCZEWSKI M, CZERSKA E, LONIEWSKA B, KACZMARCZYK M, GUMPRECHT J, GRZESZCZAK W, SZYBINSKA A, MOSSAKOWSKA M, CIENCHANOVWICZ A: An age-related decrease in factor V Leiden frequency among Polish subjects. J Appl Genet 51: 337-341, 2010.

ANTÓN AI, TERUEL R, CORRAL J, MIÑANO A, MARTÍNEZ-MARTÍNEZ I, ORDÓÑEZ A, VICENTE V, SÁNCHEZ-VEGA B: Functional consequences of the prothrombotic SERPINC1 rs2227589 polymorphism on antithrombin levels. Haematologica 94: 589-592, 2009.

AUSTIN H, DE STAERCKE C, LALLY C, BEZEMER ID, ROSENDAAL FR, HOOPER WC: New gene variants associated with venous thrombosis: a replication study in White and Black Americans. J Thromb Haemost 9: 489-495, 2011.

BERTINA RM: The prothrombin $20210 \mathrm{G}$ to A variation and thrombosis. Curr Opin Hematol 5: 339-342, 1998.

BERTINA RM, KOELEMAN BP, KOSTER T, ROSENDAAL FR, DIRVEN RJ, DE RONDE H, VAN DER VELDEN PA, REITSMA PH: Mutation in blood coagulation factor $\mathrm{V}$ associated with resistance to activated protein C. Nature 369: 64-67, 1994.

BEZEMER ID, BARE LA, DOGGEN CJ, ARELLANO AR, TONG C, ROWLAND CM, CATANESE J, YOUNG BA, REITSMA PH, DEVLIN JJ, ROSENDAAL FR: Gene variants associated with deep vein thrombosis. JAMA 299: 1306-1314, 2008.

BRAY PF, HOWARD TD, VITTINGHOFF E, SANE DC, HERRINGTON DM: Effect of genetic variations in platelet glycoproteins $\mathrm{Ib}$ and $\mathrm{VI}$ on the risk for coronary heart disease events in postmenopausal women taking hormone therapy. Blood 109: 1862-1869, 2007.

BUCKOVA D, IZAKOVICOVA-HOLLA L, VACHA J: Polymorphism $4 \mathrm{G} / 5 \mathrm{G}$ in the plasminogen activator inhibitor-1 (PAI-1) gene is associated with IgE-mediated allergic diseases and asthma in the Czech population. Allergy 57: 446-448, 2002.

CLEMETSON JM, POLGAR J, MAGNENAT E, WELLS TN, CLEMETSON KJ: The platelet collagen receptor glycoprotein VI is a member of the immunoglobulin superfamily closely related to FcalphaR and the natural killer receptors. J Biol Chem 274: 29019-29024, 1999.

CROFT SA, SAMANI NJ, TEAREMD, HAMPTON KK, STEEDS RP, CHANNER KS, DALY ME: Novel platelet membrane glycoprotein VI dimorphism is a risk factor for myocardial infarction. Circulation 104: 1459-1463, 2001.

DE LA MORENA-BARRIO ME, ANTON AI, MARTINEZ-MARTINEZ I, PADILLA J, MINANO A, NAVARROFERNANDEZ J, ÁQUILA S, LOPEZ MF, FONTCUBERTA J, VICENTE V, CORRAL J: Regulatory regions of SERPINC1 gene: identification of the first mutation associated with antithrombin deficiency. Thromb Haemost 107: 430-437, 2012. 
ERIKSSON P, KALLIN B, VAN'T HOOFT FM, BAVENHOLM P, HAMSTEN A: Allele-specific increase in basal transcription of the plasminogen-activator inhibitor 1 gene is associated with myocardial infarction. PNAS 92: 1851-1855, 1995.

GOHIL R, PECK G, SHARMA P: The genetics of venous thromboembolism. A meta-analysis involving approximately 120,000 cases and 180,000 controls. Thromb Haemost 102: 360-370, 2009.

HONZAK R: Factor V Leiden and Slovak population. Prakt Lek 12: 845-850, 1999.

HOPPE B, TOLOU F, DORNER T, KIESEWETTER H, SALAMA A: Gene polymorphisms implicated in influencing susceptibility to venous and arterial thromboembolism: frequency distribution in a healthy German population. Thromb Haemost 96: 465-470, 2006.

HRACHOVINOVA I, VORLOVA Z, MATYSKOVA M, JANKU L: Thrombotic risk of the prothrombin gene G20210A mutation and clinical features of thrombophilia in 50 carriers of mutation. Thromb Haemost, XVIIth Congress of the ISTH, Washington D.C., USA, Suppl. Abstract No. 2060: p. 652, 1999.

HUBACEK JA, STANEK V, GEBAUEROVA M, PILIPCINCOVA A, POLEDNE R, ASCHERMANN M, SKALICKA H, MATOUSKOVA J, KRUGER A, PENICKA M, HRABAKOVA H, VESELKA J, HAJEK P, LANSKA V, ADAMKOVA V, PITHA J: Lack of an association between connexin-37, stromelysin-1, plasminogen activator-inhibitor type 1 and lymphotoxin-alpha genes and acute coronary syndrome in Czech Caucasians. Exp Clin Cardiol 15: 52-56, 2010.

JOUTSI-KORHONEN L, SMETHURST PA, RANKIN A, GRAY E, IJSSELDIJK M, ONLEY CM, WATKINS NA, WILLIAMSON LM, GOODALL AH, DE GROOT PG, FARNDALE RW, OUWEHAND WH: The low frequency allele of the platelet collagen signalling receptor glycoprotein VI is associated with reduced functional responses and expression. Blood 101: 4372-4379, 2003.

KRUITHOF EKO: Regulation of plasminogen activator inhibitor type I gene expression by inflammatory mediators and statins. Thromb Haemost 100: 969-975, 2008.

LI A, JIAO X, MUNIER FL, SCHORDERET DF, YAO W, IWATA F, HAYAKAWA M, KANAI A, SHY CHEN M, ALAN LEWIS R, HECKENLIVELY J, WELEBER RG, TRABOULSI EI, ZHANG Q, XIAO X, KAISERKUPFER M, SERGEEV YV, HEJTMANCIK JF: Bietti crystalline corneoretinal dystrophy is caused by mutations in the novel gene CYP4V2. Am J Hum Genet 74: 817-826, 2004.

LI Y, BEZEMER ID, ROWLAND CM, TONG CH, ARELLANO AR, CATANESE JJ, DEVLIN JJ, REITSMA PH, BARE LA, ROSENDAAL FR: Genetic variants associated with deep vein thrombosis: the F11 locus. J Thromb Haemost 7: 1802-1808, 2009.

LUCOTTE G, MERCIER G: Population genetics of factor V Leiden in Europe. Blood Cells Mol Dis 27: 362-367, 2001.

MANOLIO TA: Genomewide association studies and assessment of the risk of disease. N Engl J Med 363: 166-176, 2010.

MARGAGLIONE M, GRANDONE E: Population genetics of venous thromboembolism. A narrative review. Thromb Haemost 105: 221-231, 2011.

MATYSKOVA M, PASEKA J, VORLOVA Z, BULIKOVÁ A, HRACHOVINOVA I, JANKU L: Prevalence of factor V Leiden mutation in healthy women. In: 29. Hämophilie Symposion Hamburg 1998. I SCHARRER, W SCHRAMM (eds), Springer Verlag, Berlin - Heidelberg, 1999, pp 309-311.

MORANGE PE, TREGOUET DA: Lessons from genome-wide association studies in venous thrombosis. $J$ Thromb Haemost 9: 258-264, 2011.

MOTOVSKA Z, KVASNICKA J, WIDIMSKY P, PETR R, HAJKOVA J, BOBCIKOVA P, OSMANCIK P, ODVODYOVA D, KATINA S: Platelet glycoprotein GP VI 13254C allele is an independent risk factor of premature myocardial infarction. Thromb Res 125: e61-e64, 2010.

NAKAN M, KELLY EJ, RETTIE AE: Expression and characterization of CYP4V2 as a fatty acid $\omega$-hydroxylase. Drug Metab Dispos 11: 2119-2122, 2009.

POORT SR, ROSENDAL FR, REITSMA PH, BERTINA RM: A common genetic variation in the 3'-untranslated region of the prothrombin gene is associated with elevated plasma prothrombin levels and an increase in venous thrombosis. Blood 88: 3698-3703, 1996. 
RENNER W, KOPPEL H, HOFFMANN CH, SCHALLMOSER K, STANGER O, TOPLAK H, WASCHER TC, PILGER E: Prothrombin G20210A, factor V Leiden, and factor XIII Val34Leu: common mutation of blood coagulation factors and deep vein thrombosis in Austria. Thrombosis Res 99: 35-39, 2000.

RIBA R, SHARIFI M, FARNDALE RW, NASEEM KM: Regulation of platelet guanylyl cyclase by collagen: evidence that Glycoprotein VI mediates platelet nitric oxide synthesis in response to collagen. Thromb Haemost 94 : 395-403, 2005.

RIDKER PM, MILETICH JP, HENNEKENS CH, BURING JE: Ethnic distribution of factor V Leiden in 4047 men and women. Implications for venous thromboembolism screening. JAMA 277: 1305-1307, 1997.

ROSENDAAL FR: Venous thrombosis: a multicausal disease. Lancet 353: 1167-1173, 1999.

TATARSKYY P, KUCHERENKO A, LIVSHITS L: Allelic polymorphism of F2, F5 and MTHFR genes in population of Ukraine. Tsitol Genet 44: 3-8, 2010.

TREGOUET DA, HEATH S, SAUT N, BIRON-ANDREANI C, SCHVED JF, PERNOD G, GALAN P, DROUET L, ZELENIKA D, JUHAN-VAGUE I, ALESSI MC, TIRET L, LATHROP M, EMMERICH J, MORGANGE PE: Common susceptibility alleles are unlikely to contribute as strongly as the FV and ABO loci to VTE risk: results from a GWAS approach. Blood 113: 5298-5303, 2009.

SCHWENDER S, GROSMANN R, KELLER F: High prevalence of factor V Leiden mutation is detected in a north to south axis through Germany. Lab Med 21: 347-353, 1997.

SNOEP JD, GAUSSEM P, EIKENBOOM JCJ, EMMERICH J, ZWAGINGA JJ, HOLMES CE, VOS HL, DE GROOT PG, HERRINGTON DM, BRAY PF, ROSENDAAL FR, VAN DER BOM JG: The minor allele of GP6 $13254 \mathrm{~T}>\mathrm{C}$ is associated with decreased platelet activation and a reduced risk of recurrent cardiovascular events and mortality: results from the SMILE-Platelets project. $J$ Thromb Haemost 8: 2377-2384, 2010.

TRIFIRO E, WILLIAMS SA, CHELI Y, FURIHATA K, PULCINELLI FM, NUGENT DJ, KUNICKI TJ: The lowfrequency isoform of platelet glycoprotein VIb attenuates ligand-mediated signal transduction but not receptor expression or ligand binding. Blood 114: 1893-1899, 2009.

WATKINS NA, O'CONNOR MN, RANKIN A, JENNINGS N, WILSON E, HARMER IJ, DAVIES L, SMETHURST PA, DUDBRIDGE F, FARNDALE RW, OUWEHAND WH: Definition of novel GP6 polymorphisms and major difference in haplotype frequencies between populations by a combination of in-depth exon resequencing and genotyping with tag single nucleotide polymorphisms. J Thromb Haemost 4: 1197-1205, 2006. 